\title{
Is the Over-education a Temporary Phenomenon? Case of Tunisian Higher Education Graduates
}

\author{
Zrelli Ben Hamida Nadia ${ }^{1, *}$ \\ ${ }^{1}$ Higher School of Economic and Commercial Sciences of Tunis, 4, Rue Abou Zakaria El, \\ Hafsi - 1089 Montfleury, Tunis \\ *Corresponding author: Tel: 216-99-893-451 E-mail: zrellinadia@yahoo.fr
}

Received: February 6, 2014 Accepted: March 21, 2014 Published: April 7, 2014

doi:10.5296/rae.v6i2.5069ＵRL: http://dx.doi.org/10.5296/rae.v6i2.5069

\begin{abstract}
This work analyzes the phenomenon of normative overeducation in the case of Tunisian higher education graduate cohort 2004. Two interrogations are presented in the survey. The first is realized 18 months after graduation and the second 3 years after. The results of the first investigation are used in the probit model to study the extent of the phenomenon of overeducation at the first recruiting. The second interrogation is used to study the overeducation time horizon. The characteristics of employment present more significant effects on the probability of overeducation than those of the training. Among characteristics we consider the stability of employment, the branch of industry and the nature of employment (public/private). Results show that there is a diplomas hierarchy vis-a-vis the risk of overeducation. The most abundant diplomas on the labor market are not only victims of unemployment but also the most exposed to the risk of overeducation. To complete this analysis we integrate the fields of study effect. Graduates of discipline receiving the mass are more exposed to the risk of overeducation. Probit estimation results using the second interrogation show that the certification does not have any effect on the probability of overeducation. Only the stability of employment presents a significant effect on the work condition improvement of Tunisian higher education graduates initially overeducated. Results are confirmed throught multiple components analysis.
\end{abstract}

Keywords: higher education, overeducation, graduates labor market, diplomas effect, multiple correspondences analyses, probit model 


\section{Introduction}

Tunisian higher education is a dual system. Institutions offering a scientific formation (engineering medicine architect) practice selective admission policy. The scarce accepted elites obtain a diploma with strong employability. Other discipline ((social sciences, law, art) receiving the mass and offer abundant diplomas on the labor market (Bachelor of Technology $(\mathrm{Bac}+3)$ and Bachelor's Degree $(\mathrm{Bac}+4))$. Under these conditions, these graduates face professional insertion problem. Nevertheless, unemployment does not represent the single problem. Beyond recruiting, a new obstacle is presented to them: overeducation. Defines as a situation where the required skills by a job are less than those obtained during the formation, the overeducation situation becomes more and more frequent.

The overeducation phenomenon is far from being a recent phenomenon. The problem was the subject of two works, “The Great Training Robbery” of Berg (1970) and “The Overeducated American” of Freeman (1976). Thus research on overeducation developed in the years 1970 after the generalization of the access to higher education. Nevertheless the higher education graduates labor market equilibrium prevented the emergence of this phenomenon. Indeed, according to Krueger (1993), technical progress went hand in hand with a high qualified labor force demand. The emergence and the diffusion of new technologies during the 80-90 had considerable effects on the organization of the tasks and the requalification of employment in many sectors, thus contributing to reinforce the mutual adequacy between education level and employment. According to Groot and Van Der Brink (2000), it was only at the beginning of the 90 that these evolutions highlight the question of the overeducation.

In this paper we proposes through a probit model to identify the determinants of a situation of overeducation for the graduates of the year 2004 become paid 18 months after obtaining their diplomas. For this purpose we used the data of investigation of the study "Employment dynamics among university graduates” carried out by Ministry of Vocational Training and Employment and World Bank.

In this paper we propose through a model probit to identify the determinants of overeducation for the graduates' cohort 2004 obtaining a job 18 months after leaving higher education system (2005). For this purpose we used the data survey of the study "Employment dynamics among university graduates” carried out by Tunisian ministry of Vocational Training and Employment and the World Bank.

To analyze the temporary character of this phenomenon two methods are used. A probit model and multiple correspondences analyses with the help of the results of the second survey carried out with the same sample of graduates 3 years after obtaining the diploma (2007).

This analysis thus presents four sections. Section 1 presents theatrical approaches of overeducation. Section 2 presents the data and methodology used. Section 3 highlight the probit estimations results and identifies the principal determinants of the overeducation 18 months after obtaining the diploma. The last section analyzes the temporary character of this phenomenon. 


\section{Theoretical approaches}

The economic theories propose several explications to the emergence and the time persistence of overeducation (Sloane \& al 1999). The human capital theory (Becker 1964) presents the over-education as a temporary phenomenon (Barone \& Ortiz 2011). The theory of the signal (Spence 1973) explains the over-education at the first job by the higher education diplomas devaluation in the labor market. The diplomas rank in the hierarchy of certifications represents its value on the labor market. The inflation of the diplomas leads to an irreversible devaluation of the school titles if initial training does not affect individual aptitudes. According to Thurrow's job competition theory (1975) employment is rationed, the employer chooses the candidate who will quickly join the standard of productivity (Bower 2002). Initial training is the principal assets for employment. Nevertheless it does not announce the individual productivity but rather the employability. So there is no direct relationship between the education level and the productivity in employment. Higher education levels ensure the capacities of adaptation confirming the formation-skills correlation for a specific employment.

The job competition theory implies the construction of a queue at the head of there is the most graduate individuals. Such hypothesis can explain the development of overeducation (Founder (1999)). Given diploma and the length of queue, individuals are brought to extend their waiting until obtaining an adequate employment or to change queue i.e. to postulate for employment less qualified. This change of queue could be the source of the overeducation.

The interest of considering the field of study is the identification of hierarchy of the fields of study for each higher educational degree. Job requiring the same skills relatively to distinct level of the ISCED (comparing the artisanal workmen with industrial workmen (Cahuzac, Lemistre and Ourtau 2000)). According to the training point of view, the fields of study with higher costs permit to reach more qualified job. The training level and fields of study plays a key role in the classification of an individual in the queue. Dauty, Lemistre and Vincens (2006) confirmed this approach through the analysis of the French education system. The standard of correspondence diploma-socio-professional category cannot neglect the taking into account the fields of study.

\section{Data and methodology}

This empirical analysis tries to explain two phenomena. On the one hand identify the individual characteristics influencing the probability of overeducation 18 months after obtaining the diploma. In order to analyze the temporary character of overeducation, we analyze, in the other hand, the phenomenon persistence and determinants 3 years and half after obtaining the diploma.

The study considers Tunisian higher education graduates cohort 2004. It is realized jointly by the Tunisian Ministry of Vocational Training and Employment and World Bank within. This study presents two surveys. The first is realized at the end of year 2005 beginning 2006 with a sample of 4763 graduates of various levels and fields of study. The second survey is 
realized at the end of 2007, i.e. 3 years and half after obtaining the diploma, with the same sample of graduates.

In this analysis we consider only graduates with "paid employment" jobs having answered the two interrogations. The sample thus counts 1125 graduates.

Table 1. Table of diploma-socio-professional category correspondence

\begin{tabular}{|c|c|c|c|c|c|c|c|c|c|c|c|c|c|c|c|}
\hline & 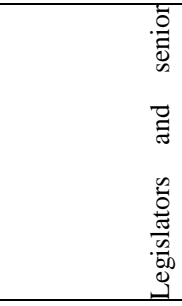 & 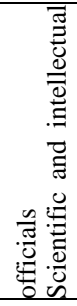 & 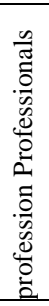 & 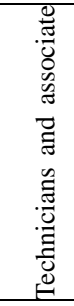 & 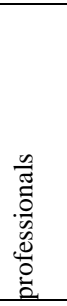 & 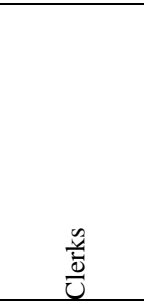 & 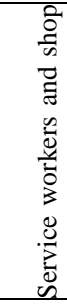 & 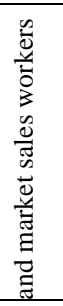 & 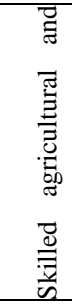 & 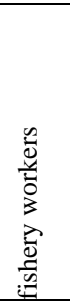 & 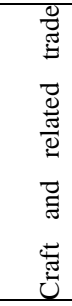 & 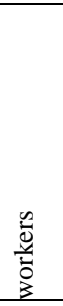 & 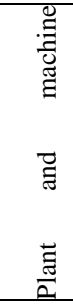 & 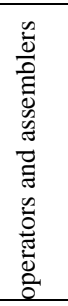 & 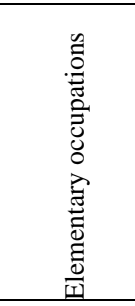 \\
\hline Bachelor & f technology & & & & & $\begin{array}{l}\text { overeducat } \\
\text { ed }\end{array}$ & $\begin{array}{l}\text { overe } \\
\text { ed }\end{array}$ & ducat & $\begin{array}{l}\text { overe } \\
\text { ed }\end{array}$ & ducat & $\begin{array}{l}\text { overe } \\
\text { ed }\end{array}$ & ducat & $\begin{array}{l}\text { overe } \\
\text { ed }\end{array}$ & ducat & $\begin{array}{l}\text { overeducat } \\
\text { ed }\end{array}$ \\
\hline Bachelor' & Degree & & & $\begin{array}{l}\text { overe } \\
\text { ed }\end{array}$ & ducat & $\begin{array}{l}\text { overeducat } \\
\text { ed }\end{array}$ & $\begin{array}{l}\text { overe } \\
\text { ed }\end{array}$ & ducat & $\begin{array}{l}\text { overe } \\
\text { ed }\end{array}$ & ducat & $\begin{array}{l}\text { overe } \\
\text { ed }\end{array}$ & ducat & $\begin{array}{l}\text { overe } \\
\text { ed }\end{array}$ & ducat & $\begin{array}{l}\text { overeducat } \\
\text { ed }\end{array}$ \\
\hline Engineer & & & & $\begin{array}{l}\text { overe } \\
\text { ed }\end{array}$ & ducat & $\begin{array}{l}\text { overeducat } \\
\text { ed }\end{array}$ & $\begin{array}{l}\text { overe } \\
\text { ed }\end{array}$ & ducat & $\begin{array}{l}\text { overe } \\
\text { ed }\end{array}$ & ducat & $\begin{array}{l}\text { overe } \\
\text { ed }\end{array}$ & ducat & $\begin{array}{l}\text { overe } \\
\text { ed }\end{array}$ & ducat & $\begin{array}{l}\text { overeducat } \\
\text { ed }\end{array}$ \\
\hline Architect & & & & $\begin{array}{l}\text { overe } \\
\text { ed }\end{array}$ & ducat & $\begin{array}{l}\text { overeducat } \\
\text { ed }\end{array}$ & $\begin{array}{l}\text { overe } \\
\text { ed }\end{array}$ & ducat & $\begin{array}{l}\text { overe } \\
\text { ed }\end{array}$ & ducat & $\begin{array}{l}\text { overe } \\
\text { ed }\end{array}$ & ducat & $\begin{array}{l}\text { overe } \\
\text { ed }\end{array}$ & ducat & $\begin{array}{l}\text { overeducat } \\
\text { ed }\end{array}$ \\
\hline Doctor & & & & $\begin{array}{l}\text { overe } \\
\text { ed }\end{array}$ & ducat & $\begin{array}{l}\text { overeducat } \\
\text { ed }\end{array}$ & $\begin{array}{l}\text { overe } \\
\text { ed }\end{array}$ & ducat & $\begin{array}{l}\text { overe } \\
\text { ed }\end{array}$ & ducat & $\begin{array}{l}\text { overe } \\
\text { ed }\end{array}$ & ducat & $\begin{array}{l}\text { overe } \\
\text { ed }\end{array}$ & ducat & $\begin{array}{l}\text { overeducat } \\
\text { ed }\end{array}$ \\
\hline $\begin{array}{l}\text { Primary } \\
\text { teacher }\end{array}$ & education & & & $\begin{array}{l}\text { overe } \\
\text { ed }\end{array}$ & ducat & $\begin{array}{l}\text { overeducat } \\
\text { ed }\end{array}$ & $\begin{array}{l}\text { overe } \\
\text { ed }\end{array}$ & ducat & $\begin{array}{l}\text { overe } \\
\text { ed }\end{array}$ & ducat & $\begin{array}{l}\text { overe } \\
\text { ed }\end{array}$ & ducat & $\begin{array}{l}\text { overe } \\
\text { ed }\end{array}$ & ducat & $\begin{array}{l}\text { overeducat } \\
\text { ed }\end{array}$ \\
\hline
\end{tabular}

Source : «Employment dynamics among university graduates »P93 Ministry of Vocational Training and Employment and World Bank (2009)

The endogenous variable is a binary variable which takes value 1 if the individual is overeducated and 0 if not. It is measured in a normative way by applying professional correspondence diploma-group relationship established by the Tunisian Ministry of Vocational Training and Employment following the example of correspondence suggested by Affichard (1981).

Principal overeducation determinant are grouped through four axes. The first includes the biographical characteristics (the sex, the marital status, the professional situation of the parents and the way of financing of the studies as an approximation of the familial financial situation). The second axis presents the tertiary education through the diploma, the fields of study, in-company training and the university institution size (as a proxy of the massification phenomenon). It should be noted that we don't consider the architects and the primary education teachers in the econometric analysis.

The last axis joined on one hand the characteristics of obtained job: company size and its nature public or private, type of the obtained contract and sector of activity. We do not consider the sectors "private education" and fishing. In addition we should consider regional unemployment rate to take into account circumstances of the job market. 
Table 2. Overeducation evolution between 2005 and 2007 according to the studied characteristics

\begin{tabular}{|c|c|c|c|c|c|}
\hline & 2005 & 2007 & & 2005 & 2007 \\
\hline Normative overeducation & $30.40 \%$ & $20.62 \%$ & Construction & $0,39 \%$ & $20,59 \%$ \\
\hline Biographical data & & & Commerce & $0,60 \%$ & $41,10 \%$ \\
\hline Man & $24,37 \%$ & $19,63 \%$ & Hotels and Restoration & $0,62 \%$ & $46,15 \%$ \\
\hline Women & $37,17 \%$ & $21,74 \%$ & Transport and Communication & $35,71 \%$ & $28,40 \%$ \\
\hline Not married & $30,77 \%$ & $20,35 \%$ & Financial activities & $31,25 \%$ & $36,36 \%$ \\
\hline Father working as legislators or senior officials & $27,34 \%$ & $19,10 \%$ & Real estate activities & $51,47 \%$ & $25 \%$ \\
\hline Working mother & $25,25 \%$ & $16,16 \%$ & Public Administration & $30,43 \%$ & $21,15 \%$ \\
\hline Public Financial support & $31,62 \%$ & $21,12 \%$ & Public education & $10,42 \%$ & $6,84 \%$ \\
\hline Job characteristics & & & Health and Social work & $27,08 \%$ & $25 \%$ \\
\hline Public sector & $17,20 \%$ & $9,84 \%$ & Social and private collective services & $53,70 \%$ & $44,44 \%$ \\
\hline$\underline{\text { Contract of adaptation and professional insertion (SIVP1) }}$ & $37,89 \%$ & $50,91 \%$ & Private education & $12 \%$ & $25 \%$ \\
\hline contract of a undetermined time (CDI) & $13,48 \%$ & $8,30 \%$ & Accommodation and food service activities & NA & $26,09 \%$ \\
\hline contract of a predetermined time (CDD) & $30,31 \%$ & $22,94 \%$ & Tertiary education characteristics & & \\
\hline Other contracts & $44,06 \%$ & $50,66 \%$ & In-company training & $29,96 \%$ & $20,10 \%$ \\
\hline Less than 10 employees & $45,70 \%$ & $48,75 \%$ & Doctor & $0 \%$ & $35,71 \%$ \\
\hline 10-49 employees & $22,26 \%$ & $26,90 \%$ & Primary education teacher & $0 \%$ & $0 \%$ \\
\hline 50_199 employees & $24,51 \%$ & $15,85 \%$ & Bachelor of technology (Baccalauréat +3 ) & $32,61 \%$ & $20,22 \%$ \\
\hline 200 employees and more & $30,98 \%$ & $13,57 \%$ & Bachelor's Degree (Baccalauréat+4) & $38,30 \%$ & $23,17 \%$ \\
\hline Not classifiable by economic activity & $0 \%$ & NA & Engineer & $11,64 \%$ & $19,86 \%$ \\
\hline Agriculture & $38,46 \%$ & $28,13 \%$ & Architect & $0 \%$ & $\mathbf{0 \%}$ \\
\hline Fishing & $100 \%$ & $0 \%$ & Bachelor of Arts & $54,55 \%$ & $30 \%$ \\
\hline Mining and quarrying & $0 \%$ & $33,33 \%$ & Education & $3,16 \%$ & $21,05 \%$ \\
\hline Construction materials industries & $42,86 \%$ & $0 \%$ & Humanities and arts & $38,73 \%$ & $20,42 \%$ \\
\hline Electricity and mechanical industries & $26,87 \%$ & $16,67 \%$ & Social sciences business and law & $49,26 \%$ & $19,76 \%$ \\
\hline Chemical industries & $13,33 \%$ & $0 \%$ & Sciences & $20 \%$ & $17,84 \%$ \\
\hline textile clothing and leather & $45,24 \%$ & $31,91 \%$ & Industrial engineering \& Construction & 19,33 & $25,28 \%$ \\
\hline Another Manufacturing industries & $39,44 \%$ & $29,55 \%$ & Agriculture & $30 \%$ & $10 \%$ \\
\hline \multirow[t]{2}{*}{ Electricity production, Gas and Water } & $0 \%$ & $0 \%$ & Health and welfare & $22,22 \%$ & $14,29 \%$ \\
\hline & & & Services & $42,11 \%$ & $26,32 \%$ \\
\hline
\end{tabular}

The comparative analysis of the data investigations (2005 and 2007) (Table $\mathrm{N}^{\circ}$ 2) shows that the percentage of graduates touched by the normative overeducation dropped by $30.40 \%$ to $20.62 \%$. Even after 3 years of experience, the fifth of the graduates are still touched by this phenomenon. This result does not coincide with the overeducation temporary character supported by the human capital theory.

The exploration of this change per characteristic shows that this phenomena was reduced in the public sector, thanks to the stability of employment and if a company have more than 200 employees. The characteristics of the university training show that, all things being equal, the overeducation persists for all the types of diplomas and of fields of studies. 


\section{Macrothink}

Research in Applied Economics

ISSN 1948-5433

2014, Vol. 6, No. 2

The next section presents an econometric analysis (probit model) of the overeducation probability with both surveys (2005 and 2007). The objective is to confirm the statistical results previously presented.

\section{Results and interpretations}

Three models are estimated using the results of 2005 surveys. The first model (Model A) includes the biographical data to which we add the characteristics of employment for the second model (Model B). The last model (Model C) introduces the various characteristics of the university formation and in particular the diploma and disciplines effect.

The results of estimates are exclusively presented in terms of marginal effects and values between brackets are robust student error.

\subsection{Biographical characteristics}

Table 3. Overeducation and biographical characteristics

\begin{tabular}{|c|c|}
\hline observations & 1125 \\
\hline log likelihood & -679.806 \\
\hline Wald Chi2 & 20.95 \\
\hline Prob & 0.0008 \\
\hline Pseudo $\mathrm{R}^{2}$ & 0.0187 \\
\hline Sensitivity & $0 \%$ \\
\hline Specificity & $100 \%$ \\
\hline Correctly classified & $69.60 \%$ \\
\hline Roc curve & 0.5980 \\
\hline man & $\begin{array}{c}-12.35 \% \# \\
(0.000)\end{array}$ \\
\hline married & $\begin{array}{c}-\mathbf{1 1 . 6 1 \% \# \# ~} \\
(0.021)\end{array}$ \\
\hline Father working as legislators or senior officials & $\begin{array}{l}-2.53 \% \\
(0.479)\end{array}$ \\
\hline Working mother & $\begin{array}{l}-6.42 \% \\
(0.205)\end{array}$ \\
\hline Studying State Financial Support & $\begin{array}{l}1.92 \% \\
(0.587)\end{array}$ \\
\hline $\begin{array}{l}\text { \# : significant at } 1 \% \text { level } \\
\text { \#\# : significant at } 5 \% \text { level }\end{array}$ & \\
\hline \#\#\#: significant at $10 \%$ level & \\
\hline
\end{tabular}



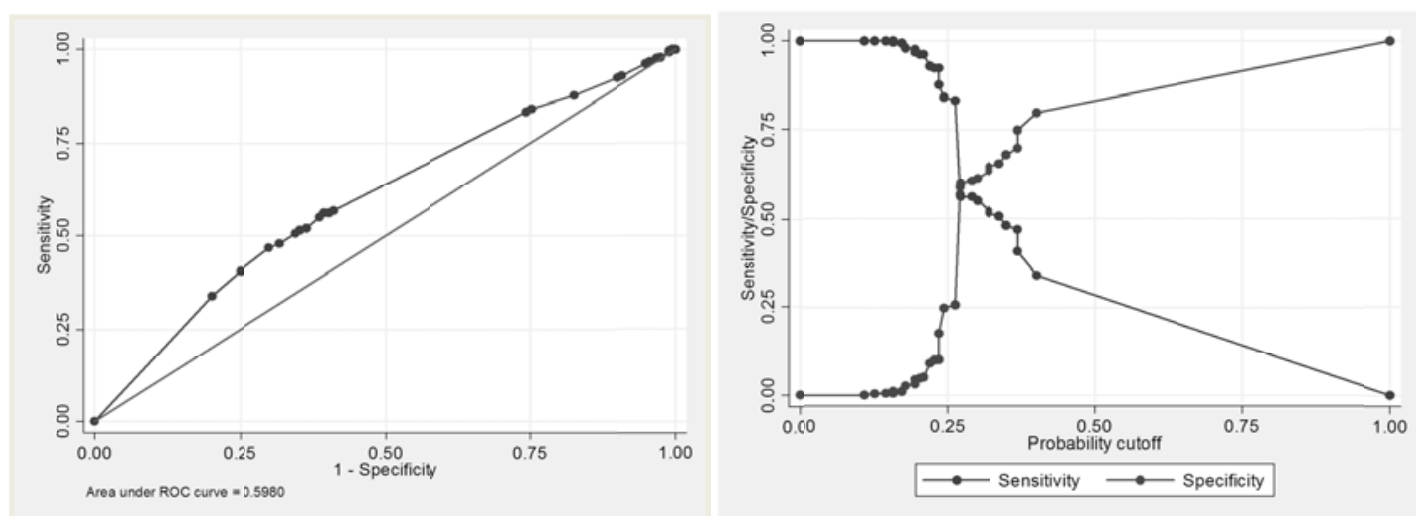

Source: Source: Author’s calculations

Figure 1. Discriminate power of probit model with biographical data

The model correctly predicts $69.60 \%$ of the cases. But by considering exclusively biographical variables the power of the model's predicted values to discriminate between positive and negative cases is too weak (sensitivity $=0 \%$ and specificity $=100 \%$ ).

The estimations results shows that, among the biographical variables, only the sex and the marital status affect negatively and significantly the probability of overeducation. Indeed a woman has $12.35 \%$ of chance in addition to being overeducated compared to a man. Moreover a married person presents $11.61 \%$ of chance in less to be overeducated.

\subsection{Job characteristics}

The characteristics of the first employment are represented by the nature of employment (public or private sector), the job stability (the type of contract) and, finally, the sector of activity. To consider the job market situation, we also introduced regional rate of unemployment. Estimation results are presented in (Table 4). 
Table 4. Overeducation and job characteristics

\begin{tabular}{|c|c|c|c|}
\hline \multicolumn{2}{|l|}{ observations } & \multicolumn{2}{|l|}{1107} \\
\hline log likelihood & -543.703 & Pseudo $R^{2}$ & 0.2074 \\
\hline Wald Chi2 & 225.97 & Correctly classified(Istat) & $74.16 \%$ \\
\hline Prob & 0.0000 & Roc curve & 0.7826 \\
\hline Sensitivity & $43.70 \%$ & Specificity & $87.73 \%$ \\
\hline Regional unemployment rate & $\begin{array}{l}0.59 \% \\
(0.185)\end{array}$ & Public sector & $\begin{array}{l}-4.29 \% \\
(0.411)\end{array}$ \\
\hline \multicolumn{2}{|l|}{ Type of contract } & \multicolumn{2}{|l|}{ Company size } \\
\hline Contract of adaptation and professional insertion ( SIVP1) & $\begin{array}{l}4.87 \% \\
(0.051)\end{array}$ & Less than 10 employees & $\begin{array}{l}0.92 \% \\
(0.046)\end{array}$ \\
\hline Contract of a predetermined time (CDD) & $\begin{array}{c}10.59 \% \text { \# } \\
(0.051)\end{array}$ & 10-49 employees & $\begin{array}{r}\mathbf{8 . 0 6 \%} \text { \#\# } \\
(0.040)\end{array}$ \\
\hline Contract of a undetermined time (CDI) & Reference & 50_199 employees & $\begin{array}{l}5.13 \% \\
(0.043)\end{array}$ \\
\hline Other types & 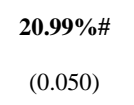 & 200 employees and more & reference \\
\hline \multicolumn{4}{|c|}{ sectors of activities: reference public education } \\
\hline Mining and quarrying & $\begin{array}{l}29.76 \% \\
(0.219)\end{array}$ & Building & $\begin{array}{r}37.54 \% \\
(0.104)\end{array}$ \\
\hline Construction materials industries & $\begin{array}{l}22.21 \% \\
(0.346)\end{array}$ & Agriculture & $\begin{array}{r}\mathbf{3 8 . 9 7 \%} \text { \# } \\
(0119)\end{array}$ \\
\hline Chemical industries & $\begin{array}{l}11.95 \% \\
(0.516)\end{array}$ & Transport and Communication & $\begin{array}{r}39.50 \% \\
(0.084)\end{array}$ \\
\hline Electricity production, Gas and Water & $\begin{array}{l}22.13 \% \\
(0.236)\end{array}$ & Another Manufacturing industries & $\begin{array}{r}\mathbf{4 0 . 3 3 \%} \text { \# } \\
(0.095)\end{array}$ \\
\hline Public administration & $\begin{array}{l}19.65 \% \\
(0.123)\end{array}$ & textile clothing and leather & $\begin{array}{r}\mathbf{4 3 . 9 8 \%} \text { \# } \\
(0.104)\end{array}$ \\
\hline Health and Social work & $\begin{array}{l}10.41 \% \\
(0.076)\end{array}$ & Real estate activities & $\begin{array}{r}\mathbf{4 5 . 4 5 \%} \\
(0.083)\end{array}$ \\
\hline Private education & $\begin{array}{c}-8.96 \% \\
(0.100)\end{array}$ & Social and private collective services & $\begin{array}{r}49.94 \% \\
(0.079)\end{array}$ \\
\hline Electricity and mechanical industries & $\begin{array}{c}\mathbf{2 0 . 2 2 \%} \# \# \\
(0.105)\end{array}$ & Commerce & $\begin{array}{r}\mathbf{5 4 . 4 5 \%} \text { \# } \\
(0.072)\end{array}$ \\
\hline Financial activities & $\begin{array}{c}22.33 \% \text { \# } \\
(0.108)\end{array}$ & Hotels and Restoration & $\begin{array}{r}54.67 \% \\
(0.099)\end{array}$ \\
\hline
\end{tabular}

Job characteristics analysis shows that regional unemployment rate and the nature of the establishment (public or private) do not have any significant effect on the probability of overeducation. Stability of employment on the other hand presents a significant effect. Indeed, obtaining a job with a contract of a predetermined time (CDD) presents $10.59 \%$ of chance to 


\section{Macrothink Institute ${ }^{\mathrm{TM}}$}

being overeducated compared to a contract in (CDI). So the career path presents overeducation principal determinants comparing to the other job characteristics.

These two resulted are mainly explained by the fact that $27 \%$ of employees with Contract of a predetermined time (CDD) in general public sector and $40 \%$ in public education.

In Tunisia the State is the principal employer of the higher education graduates. The entry in the public sector passes imperatively by the national exams based on the qualification what reduces considerably the risk of overeducation and guarantee the skills-job adequacy.

Size of the recruiting institution shows that working in an establishment with more than 200 employees represents $8.06 \%$ of chance in less to be overeducated. This result confirms the economic theory according to which large companies generally having a better definite qualification structure what lead to weaker risk of overeducation.

Sectors of activity shows that sector of commerce and hotel and restoration presents overeducation probabilities higher than $50 \%$ (respectively $54.45 \%$ and $54.67 \%$ ) compared to the sector of reference i.e. public education. Sectors which present more than $30 \%$ of chance to be overeducated compared to public education engage mainly Bachelor of technology and Bachelor's degree. We can thus advance that more the diploma are abundant on the labor market more the overeducation risk is important. This thesis according to which the inflation of the school titles generates their devaluation and increasing consequently the risk of overeducation is confirmed in the case of Tunisia. Is the analysis of the diploma effect and discipline of study will be able to affirm this conclusion?
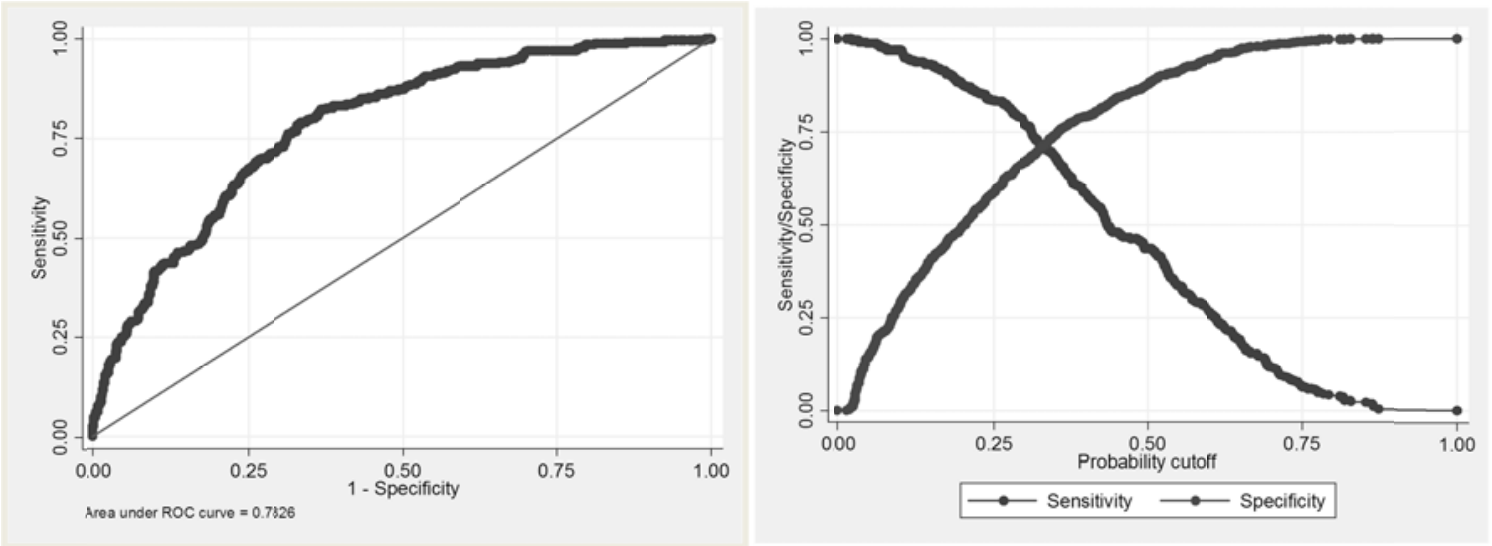

Source: Author calculations

Figure 2. Discriminate power of probit model with job characteristics

\subsection{Tertiary education characteristics}

We note that primary education teachers, doctors and architect are dropped. 
Table 5. Overeducation and training characteristics

\begin{tabular}{|c|c|}
\hline Observations & 1027 \\
\hline Log pseudo likelihood & -502.716 \\
\hline Wald Chi2 & 248.90 \\
\hline Prob $>$ Chi2 & 0.0000 \\
\hline Pseudo $R^{2}$ & 0.2407 \\
\hline Sensitivity & $53.08 \%$ \\
\hline Specificity & $86.30 \%$ \\
\hline Correctly classified (Istat) & $75.27 \%$ \\
\hline Roc curve & 0.8163 \\
\hline In-company training & $\begin{array}{l}-0.09 \% \\
(0.942)\end{array}$ \\
\hline \multicolumn{2}{|c|}{ Kinds of graduates: reference Bachelor's Degree (Baccalauréat +4 ) } \\
\hline Doctor & NA \\
\hline Bachelor of technology ( Baccalauréat +3 ) & $\begin{array}{c}-\mathbf{- 1 5 . 6 3 \% ~ \# ~} \\
(0.043)\end{array}$ \\
\hline Engineer & $\begin{array}{c}-27.57 \% \# \\
(0.030)\end{array}$ \\
\hline Bachelor of arts & $\begin{array}{c}-12.06 \% \\
(0.137)\end{array}$ \\
\hline Fields of study :reference Social sci & \\
\hline Education & $\begin{array}{c}\mathbf{- 1 8 . 7 0 \% ~ \# \# ~} \\
(0.079)\end{array}$ \\
\hline Humanities and arts & $\begin{array}{l}2.08 \% \\
(0.058)\end{array}$ \\
\hline Sciences & $\begin{array}{c}\mathbf{- 1 0 . 9 1 \% \# \# ~} \\
(0.047)\end{array}$ \\
\hline Industrial engineering \& Construction & $\begin{array}{c}-12.32 \% \# \# \\
(0.048)\end{array}$ \\
\hline Agriculture & $\begin{array}{l}5.01 \% \\
(0.217)\end{array}$ \\
\hline Health and welfare & $\begin{array}{c}-\mathbf{1 5 . 0 4 \% \# \# ~} \\
(0.64)\end{array}$ \\
\hline Services & $\begin{array}{l}5.69 \% \\
(0.130)\end{array}$ \\
\hline
\end{tabular}



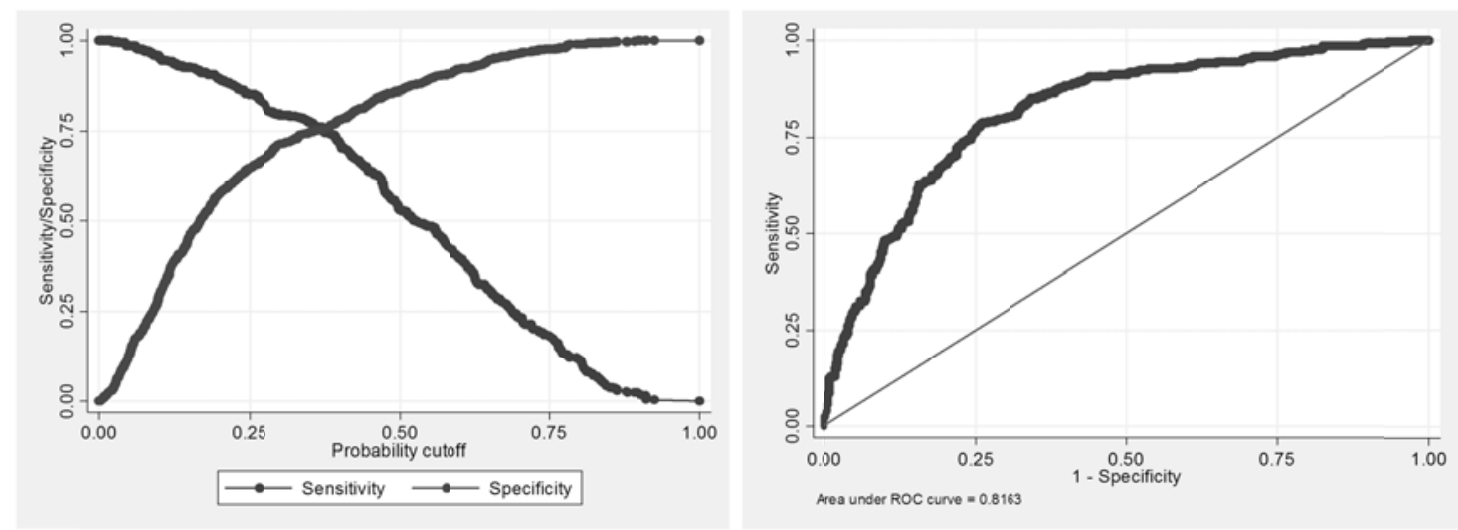

Figure 3. Discriminate power of probit model with training characteristics

The power of the model's predicted values to discriminate between positive and negative cases is quantified by the sensitivity, specificity and the Area under the ROC curve.

The comparison of the three estimated models watches that the explanatory capacity and discriminate capacity improve as we add the explanatory variables relating to the characteristics of employment and the university course. Indeed the compromise between specificity and sensitivity is reached when all the explanatory variables are introduced in the estimation (model C) (model has: sensitivity $=0 \%$, specificity $=100 \%$, model C: sensitivity= $53.08 \%$, specificity $=86.03 \%$ ). This improvement is confirmed with the area under the ROC curve witch pass from 0.598 (model A) to 0.8631 (model C) reflecting an excellent discriminatory capacity.

Table 6. Comparative analysis of explanatory capacity

\begin{tabular}{cccccc}
\hline & df & AIC & BIC & LR chi2 & Prob $>$ Chi2 \\
\hline model A & 6 & 1365.393 & 1395.546 & & \\
model B & 30 & 1185.446 & 1336.212 & $227.95 *$ & 0.0000 \\
model C & 40 & 1106.506 & 1307.528 & $98.94^{* *}$ & 0.0000 \\
\multicolumn{5}{c}{ *: Assumption : A nested in B **: *: Assumption : B nested in C } \\
\hline
\end{tabular}

The Pseudo $\mathrm{R}^{2}$ of Mc Fadden posts a continual increase as we adds explanatory variables passing from $1.87 \%$ for the model A to $24.07 \%$ for model C. The logarithm of probability presents the same evolution affirming improvement of the explanatory capacity of the model. LR test consists in considering the model constrained and the not-constrained model to obtain statistics corresponding to the variation of the logarithms of probability which makes it possible to highlight the improvement of the explanatory capacity of the model. In our estimation the log likelihood passed from -679.806 with model A to -502.716 with model C affirming the improvement of the explanatory capacity of the overeducation probability.

To analyze the contribution of each characteristic we proceeded to the comparison of the three models in term of explanatory capacity. The econometric tools used with this fact are the likelihood-ratio tests (LRtest) and the AIC and BIC information criteria.

LR test is computed by comparing the log likelihood from each model to that of a precedent 
model. Similarly for AIC and BIC criteria which refers to difference in model information with and without the variable and coefficient in question.

The hypothesis that job characteristics are simultaneously equal to zero can be rejected at the .01 level $(\mathrm{LRX} 2=227.95, \mathrm{p}<0.01)$. Similarly he hypothesis that training characteristics are simultaneously equal to zero can be rejected at the .01 level (LRX2 =98.94, p < 0.01).

The LRtest results shows also that job characteristics bring a more important explanatory capacity of the probability of downgrading than training characteristics. All else being equal, the model with the smaller AIC is considered the better fitting model. Moreover the more negative the BIC the better the fit. The difference in the BICs from three models indicates considering all the characteristics are more likely to have generated the observed data.

Table 7. Wald tests of training characteristics

\begin{tabular}{lll}
\hline Polytomique variables & Chi2 $(\mathrm{N})$ & Prob $>$ Chi2 \\
\hline Diploma & 29.31 & 0.0000 \\
Fields of study & 15.55 & 0.0296 \\
\hline
\end{tabular}

According to Wald test results, we can reject the hypothesis that the effects of diploma and fields of study are simultaneously zero.

The analysis of the diploma effect vis-a-vis the overeducation risk highlights a certain hierarchy. Become an engineer present $27.57 \%$ of chance in less to be overeducated compared to a Bachelor's Degree. A diploma of Bachelor of Arts presents $12.06 \%$ of chance in less to be overeducated (knowing that this category accounts for only $0.98 \%$ of the graduates)

What draws our attention it is the fact that the Bachelor of technology represent less than $15.63 \%$ of probability of to be overeducated compared to a Bachelor's Degree. Two arguments can explain this result. The training of Bachelor of technology in Tunisia it's distinguished mainly by its professionalization. During the university formation, this course imposes in-company trainings what improves its employability and reinforces its adequacy with the labor market needs. Moreover the title of Bachelor of technology is less abundant than the Bachelor's Degree (they represent in our sample of the respective rate of $32.98 \%$ and 45.96\%).We can thus advance that the overeducation risk is closely dependant on the abundance of the school title on the labor market and on its professionalization.

These results are confirmed by the overeducation probabilities relatively to the fields of reference, social science business and low. The latter is considered by its massification and training into total discordance with the labor market needs.

Unfortunately we cannot conclude about the humanities and arts, agriculture or services fields given they non significant coefficients.

\subsection{Overeducation determinants 3 years after}

The analysis of the overeducation transitory character is realizable through two stages. The first consists in studying the overeducation principal determinants three years after obtaining 
the diploma. We consider only determinants which changed between the two surveys (2005 and 2007). These determinants are exclusively the job characteristics (Table 6).

Table 6. Overeducation determinants 3 years after obtaining diploma

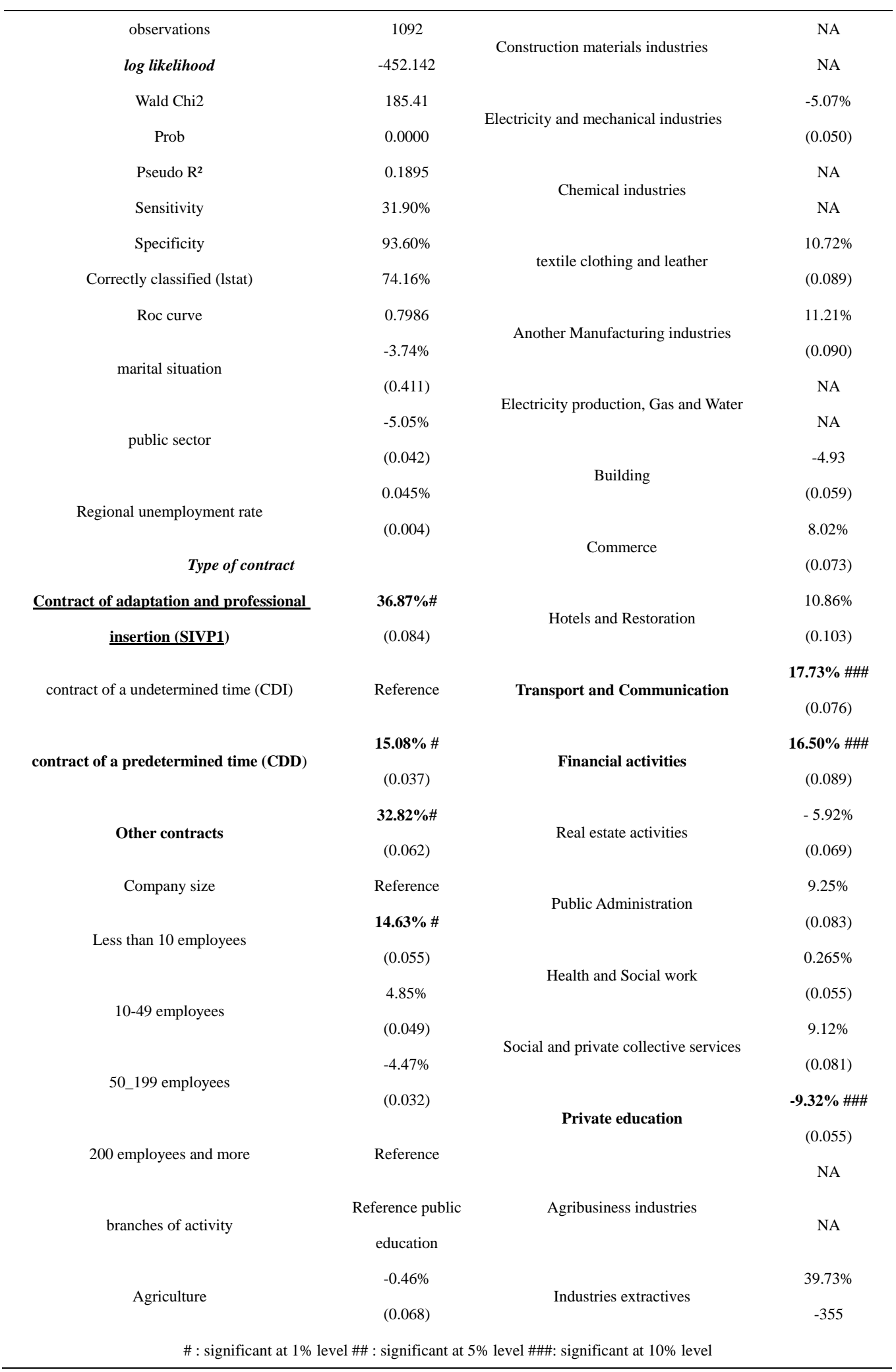


We note that Construction materials industries, Chemical industries, Electricity production, Gas and Water and Agribusiness industries are dropped.
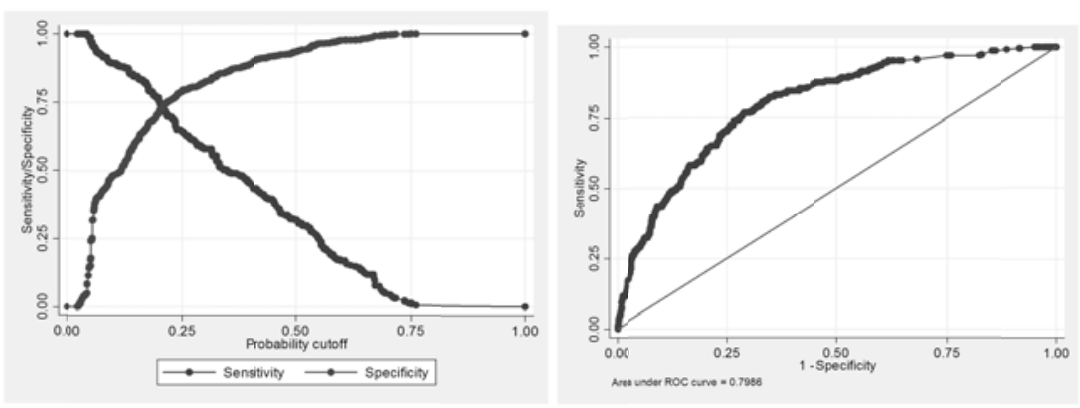

Figure 3. Discriminate power of probit model relative to the second survey data

Table 7. Explanatory capacity of politomic variables

\begin{tabular}{lll}
\hline Polytomic variables & Chi2 $(\mathrm{N})$ & Prob $>$ Chi2 \\
\hline contract type & 43.83 & 0.0000 \\
Company size & 14.72 & 0.0000 \\
Activity sectors & 29.98 & 0.0120
\end{tabular}

3 years after obtaining the diploma the principal overeducation determinant is the job stability. This is confirmed by Wald test (Table 7). Indeed between the two surveys majority of the employees with contract of a predetermined time stabilized their employment situation by obtaining a contract of a undetermined time and, simultaneously, change of socio-professional category.

Table 8. Correlation transformed variables

\begin{tabular}{cccccccc}
\hline & $\begin{array}{c}\text { Overeducation } \\
\text { 2005 }\end{array}$ & $\begin{array}{c}\text { Overeducation } \\
2007\end{array}$ & $\begin{array}{c}\text { Public } \\
\text { sector }\end{array}$ & $\begin{array}{c}\text { Type of } \\
\text { contract }\end{array}$ & $\begin{array}{c}\text { Sector of } \\
\text { activity }\end{array}$ & Diploma & $\begin{array}{c}\text { Company } \\
\text { size }\end{array}$ \\
\hline $\begin{array}{c}\text { Overeducation } \\
\text { 2005 }\end{array}$ & 1 & 0.036 & 0.047 & 0.044 & 0.043 & -0.001 & 0.024 \\
$\begin{array}{c}\text { Overeducation } \\
\text { 2007 }\end{array}$ & 0.036 & 1 & 0.26 & 0.391 & 0.265 & 0.044 & 0.278 \\
Public sector & 0.047 & 0.26 & 1 & 0.463 & 0.782 & 0.035 & 0.464 \\
Type of contract & 0.044 & 0.391 & 0.463 & 1 & 0.485 & 0.048 & 0.523 \\
Sector of activity & 0.043 & 0.265 & 0.782 & 0.485 & 1 & 0.05 & 0.462 \\
Diploma & -0.001 & 0.044 & 0.035 & 0.048 & 0.05 & 1 & 0.072 \\
Company size & 0.024 & 0.278 & 0.464 & 0.523 & 0.462 & 0.072 & 1 \\
Dimension & 1 & 2 & 3 & 4 & 5 & 6 & 7 \\
Eigenvalue & 2.805 & 1.004 & 0.991 & 0.879 & 0.648 & 0.457 & 0.217 \\
\hline
\end{tabular}

The multiple components analysis confirms the results found through the overeducation probability estimation 3 years after obtaining the diploma. Indeed the matrix of correlation shows that the stability of employment, the sector of activities and the company size are the principal's overeducation determinants 2007. Tertiary education training characteristics formations do not present any significant effect on the overeducation probability. 


\section{Conclusion}

$30 \%$ of Tunisian higher education graduates can reach an employment only at the price of an overeducation situation. This phenomenon takes all its extensity since the graduate leave the higher educational system. He is particularly current among the most abundant graduates (i.e. bachelor degrees and bachelor of technologies). And who's which the fields of study is characterized by a laxest admission policy from explaining its massification. The overeducation probabilities define a diplomas hierarchy explained by their abundance and professionalization. Within the framework of Tunisian higher education graduates the theory of competition for employment is checked. Indeed the "Bac +4 " is obliged to change queue and become competitors with the "Bac +3 " explaining their overeducation.

After 3 years of the date of obtaining the diploma overeducation touches only the fifth of the graduates. This improvement is explained mainly by the path career. Training university represented exclusively by the diploma does not present any effect. According to the obtained resulats, to slow down the overeducation expansion public decions maker must adopt more severe admission policy and accentuate on the fields of studies that satisfy labor market needs.

\section{References}

Affichard, J. (1981). Quels emplois après l'école: la valeur des titres scolaires depuis 1973. Économie et statistique, 134(1), 7-26. http://dx.doi.org/10.3406/estat.1981.4497

Barone, C., \& Ortiz, L. (2011). Overeducation among European University Graduates: a comparative analysis of its incidence and the importance of higher education differentiation. Higher Education, 61(3), 325-337. http://dx.doi.org/10.1007/s10734-010-9380-0

Bauer, T. K. (2002). Educational mismatch and wages: a panel analysis. Economics of Education Review, 21(3), 221-229. http://dx.doi.org/10.1016/S0272-7757(01)00004-8

Becker, G. S. (1964). Human capital theory. Columbia University Press for the National Bureau of Economic Research, New York.

Berg, I. (1970). Education for Jobs; The Great Training Robbery.

Cahuzac, E., Lemistre, P., \& Ourtau, M. (2000). Équité versus efficacité des politiques d'éducation: le cas du CAP. In Efficacité versus équité en économie sociale, Ed Lharmattan, Paris, pp.13-24.

Dauty, F., \& Lemistre, P. (2010). Diversité des parcours éducatifs: quel impact sur le chômage et les salaires?. Formation emploi, 111(3), 5-18. http://dx.doi.org/10.3917/form.111.0005

Fondeur, Y., \& Minni, C. (1999). Le déclassement à l'embauche. Etude réalisée pour le Commissariat. 
Freeman, R. B. (1976). Individual mobility and union voice in the labor market. The American Economic Review, 66(2), 361-368.

Groot, W., \& Maassen Van Den Brink, H. (2000). Overeducation in the labor market: a meta-analysis. Economics of education review, 19(2), 149-158. http://dx.doi.org/10.1016/S0272-7757(99)00057-6

Krueger, A. B. (1993). How computers have changed the wage structure: evidence from microdata, 1984-1989. The Quarterly Journal of Economics, 108(1), 33-60. http://dx.doi.org/10.2307/2118494

Sloane, P. J., Battu, H., \& Seaman, P. T. (1999). Overeducation, undereducation and the British labour market. Applied Economics, 31(11), 1437-1453. http://dx.doi.org/10.1080/000368499323319

Spence, M. (1973). Job market signaling. The quarterly journal of Economics, 87(3), 355-374. http://dx.doi.org/10.2307/1882010

Thurow, L. C. (1975). Generating inequality.

\section{Copyright Disclaimer}

Copyright reserved by the author(s).

This article is an open-access article distributed under the terms and conditions of the Creative Commons Attribution license (http://creativecommons.org/licenses/by/3.0/). 